\title{
Access of Fisheries Information to Fishers in Lake Tana, Amhara Region, Ethiopia
}

\author{
Eyob Bezabeh \\ Ethiopian Istitute of Agricultural Research \\ National Fishery and Aquatic Life Research Center
}

\begin{abstract}
Lake Tana is Ethiopia's largest lake which carries more than $80 \%$ of the total volume of Nile River. The objective of this study was to analyze fisheries' access to information and technologies in Lake Tana. Raw data collected from four landing sites of Lake Tana (Bahird Zuria, Gorgora, Metreabaworka and Bata kebele) and filled in STATA by Nationa Fishery and other Aquatic Life Research Center, Agricultural Research Directorate was used. Then the data was analysed using simple descriptive statistics. According to the result, most of the fishers $(71.4 \%)$ were male. the result revealed that the majority of fishers were between the age range of 20 and 54 years. On the other hand the result depicts that half of $(50.6 \%)$ of the fishers had no formal education, while others have been educated from grade 1 up to diploma level. According to the result $85.7 \%$ of the fishers were married, while $9.9 \%$ of them were unmarried. On the other hand Fishing experience ranged between 1 and 30 years, with the mean of 12.2 years. The majority of respondents $(88 \%)$ revealed that they got advisory services and trainings from woreda experts and development agents. But, the woreda experts as well as development agents use camp to camp visit to get fish producers and also they arrange trainings when some fish producers are busy on their job. So, to have efficient and effective fishing practice the concerned body has to expand the way of transferring technologies to the fishers through electronic media, bulletins and so on. On the other hand the woreda need to arrange trainings according to fishers' preferable schedule.
\end{abstract}

Keywords: fishers, Lake Tana, Ethiopia, Bahirdar, Amhara Region, access to information

DOI: $10.7176 /$ RHSS/9-21-01

Publication date: November $30^{\text {th }} 2019$

\section{Introduction}

In Ethiopia the agricultural sector is a corner stone of the economic and social life of the people, where about 12 million smallholder farming households account for an estimated 95 percent of agricultural production. The sector has been contributing about $43 \%$ of the GDP, more than $70 \%$ of employment and $90 \%$ of total export earnings, $98 \%$ of total calorie supply as well as providing about $70 \%$ of the raw materials for the manufacturing industrial sector (FAO., 2011, Aleme A. and Lemma Z. 2015). But the country is still facing the challenge in producing adequate food for a rapidly growing population even if it is known to be the habitat for diverse flora and fauna (Redeat, 2012; wuletaw 2018). All this things brought the government to develop a growth and transformation plan because the sector requires substantial transformation to sustain the increase in crop and livestock production and productivity (NPC, 2016).

The livestock is an integral part of agricultural sector which plays significant role in Ethiopia's economy. As the report of CSA (2017), the livestock sector accounts about $33 \%$ of agricultural GDP and also has a share of 12 to 15 percent from the total GDP of the country. Fishery is one of the integral and important commodities of livestock that provides not only food and raw materials but also it is a pertinent commodity for the socioeconomic, macroeconomic like foreign currency and creates area for employment of women and youths (Agumassie Tesfahun 2018). According to FAO 2015, the fisheries sector generated 13,200 employments in the country.

Ethiopia, which has a surface area of 1.127 million $\mathrm{km}^{2}$, is a land locked country depending only on inland water resources for the supply of fish. The country has $7740 \mathrm{~km}^{2}$ coverage of lakes, $1447 \mathrm{~km}^{2}$ coverage of large dams and $4000 \mathrm{~km}^{2}$ small rivers which are conducive for the fish farm practice. In this regard the country has a potential of fish production of 94,500. From this Lake Tana took the lion share (Abebe G. and Eshete D., 2012, G. Tesfaye and M. wolf 2014).

Lake Tana is Ethiopia's largest lake and which is situated in the northwestern at an altitude of approximately 1800 masl and accounts $50 \%$ of the total standing water area of the country. More than 5400 fisheries are dependent on the lake for their livelihood (Erkie A. 2017). The lake provides three commercially important fishes namely, African Cat fish (Clarius gariepinus also locally called "Ambaza"), Nile tilapia (Oreochromis niloticus, locally called "Kereso") and Labeobarbus spp. (locally called "Nech Asa") (Kidane M. and Adiss G. 2016, Amare D, et al 2018). Different studies had been conducted on Lake Tana but lack to address in evaluating access of the fishers to advisory services and fisheries information and sources of information as well as the means the information was transferred to them.

Therefore the focus of this study is to evaluate the access of fisheries information to fish farmers in Lake 
Tana, Ethiopia. Different studies revealed that, access to information and the way the information reached to the fishers is a matter for the sake of adopting or not adopting the technologies (Kaleb, 2017, Gurmesa 2011, Haruna M.A. 2015). Farmers to accept the recommendations as well as technologies generated from the research centers information and advisory services has great influence (Abdul H.A and Awal A.R 2016, Mekonnen Sime, FissehaZegeye, Bedru Beshir and BezawitYilama 2015). On the other hand, as Selamu Abraham and Lelise Mitiku 2018, recommended on their study that, when a technology is transferred to fishers or other actors in the value chain of fish marketing it had to be through guidance and taught so as they updated their habit of fish production, management and harvesting. And this leads the farmers to improve the sector.

Hence, as this study was focused on analyzing the access of fishers to the information from different stakes, the result help those who are the concerned bodies in giving them the required insight to improve the way they are giving information to the fish producers of Lake Tana.

\section{Methodology}

The raw data was taken from National Fishery and other Aquatic Life Research Center, Agricultural Research Directorate data base which was collected from 91 fish producers from four landing sites of Lake Tana (Bahird Zuria, Gorgora, Metreabaworka and Bata kebele). This study analyzed the data using STATA. The study used simple descriptive statistics for the analysis.

\section{Results and discussion \\ Socio economic characteristics of the respondents}

The economic characteristics of the respondents examined were presented in the table below. The variables considered include gender, age, educational level, number of years spent in formal education, marital status, household size and years of experience in fishing.

The result in the table below (Table 1) revealed that $71.4 \%$ of the fishers were male while $28.6 \%$ were female. It can therefore infer that most of the fishers in the study area were male. This could be because fishing activities in the study area considered or viewed as a man's job.

The result in the table below (Table 1) showed that most of the fishers are between the age range of 20 and 54 years. The result shows high level of participation of productive youths in the fish production activities in the study area. The implication being that the fish industry provided job opportunity.

The result on the table below (Table 1) depicts that the level of education among the respondents. Half of $(50.6 \%)$ of the fishers had no formal education, while others have been educated from grade 1 up to diploma level.

The table (Table 1) also revealed that $85.7 \%$ of the fishers were married, while $9.9 \%$ of them were unmarried. On the other hand Fishing experience ranged between 1 and 30 years, with the mean of 12.2 years. In fact, $44 \%$ fished for about 1 to 10 years. $40 \%$ of the fishers had 11 to 20 , and $12 \%$ had over 20 years of fishing experience. 
Table 1. distribution of respondents on their socioeconomic characteristics $(n=91)$

\begin{tabular}{ll}
\hline variable & Frequency \\
Gender & \\
Male & $66(71.4)$ \\
Female & $26(28.6)$ \\
Age & \\
$<24$ & $7(7.7)$ \\
$25-54$ & $82(90.1)$ \\
$55-64$ & $2(2.2)$ \\
Educational level & \\
No formal education & $46(50.6)$ \\
1 up to 6 grade & $26(28.6)$ \\
7 up to 12 grade & $18(19.8)$ \\
Diploma & $1(1.1)$ \\
Marital status & \\
Married & $78(85.7)$ \\
Unmarried & $9(9.9)$ \\
Divorce & $3(3.3)$ \\
Widowed & $1(1.1)$ \\
Household size & \\
$1-3$ & $13(14)$ \\
$4-5$ & $37(41)$ \\
$6-8$ & $37(41)$ \\
$>8$ & $4(4)$ \\
Mean & 1.2 \\
Experience with fishing activity & \\
$1-10$ & $40(44)$ \\
$11-20$ & $36(40)$ \\
$>20$ & $15(12)$ \\
Mean & 12.2 \\
\hline &
\end{tabular}

\section{Access to fisheries information}

If take a look at table 2 , the majority of respondents $(88 \%)$ revealed that they got access to fisheries information and advisory services by woreda experts and development agents. On the other hand the respondents indicated that, they got market information like quality requirements of the market and price information from their fish customers. But those who do not get all these market information (about five respondents in head count) were more than 120 minutes far from the nearest market place. And this may affect them to get updated information.

Table 2: access to fisheries information $(n=91)$

\begin{tabular}{lll}
\hline $\begin{array}{l}\text { Do you get access to fisheries } \\
\text { information }\end{array}$ & Frequency- No of respondents & Percent \\
Yes & 80 & 88 \\
No & 11 & 12 \\
Total & 91 & 100
\end{tabular}

Among these respondents who do have access to fisheries information and advisory services, $90 \%$ of them are under the age group of 25 to $54,2.5 \%$ are above 54 years old and $7.5 \%$ are below 24 years old (Table 3 ). And this result indicated that young fishers do have more exposure to access to information.

Table 3: Access to fisheries information by age category

$\begin{array}{cccc}\text { Access to fisheries } & <24 \text { years old } & 25 \text { to } 54 \text { years old } & >54 \text { years old } \\ \text { information } & 6 & 72 & 2 \\ \text { Yes } & 1 & 10 & 0 \\ \text { No } & \mathbf{7} & \mathbf{8 2} & \mathbf{2}\end{array}$

Table 4 showed the result on access of respondents to fisheries information in gender wise. And we can depict from the table that, from the 26 women respondents $23(89 \%)$ of them had access to fisheries information, this indicates that most of the female headed fishers do have exposure to the fisheries information. But the female headed fishers do get the information and/or advisory services when the development agents as well as woreda experts come to their camp, while some of the male headed fishers do get the access to fisheries information/advisory services by experience sharing and on the organized trainings. May be this is because, 
most of the time males do have freedom of mobility so that they got the chance to participate in different meetings and trainings and this make them to face different pear groups to get the access to fisheries information by sharing their experience.

Table 4: Access to fisheries information by gender

$\begin{array}{ccc}\text { Access to fisheries information } & \text { Male headed } & \text { Female headed } \\ \text { Yes } & 57 & 23 \\ \text { No } & 8 & 3 \\ \text { Total } & 65 & 26\end{array}$

The average distance of the respondents from the nearest development center was recorded to be 24 minutes. Therefore as we can depict from table 5 the majority $(84 \%)$ of the respondents who had access to fisheries information were less than 30 minutes far from the nearest development centers, while $16 \%$ of the respondents were greater than 30 minutes far from the nearest development center but, they got access to the fisheries information. This implies that, the development agents do not bind them to reach to the fishers to give the required information and advisory services.

Table 5: distance of respondents' residence from development center in minutes

$\begin{array}{ccccc}\begin{array}{c}\text { Access to fisheries } \\ \text { information }\end{array} & 30<\mathrm{D}<=60 & 60<\mathrm{D}<=90 & 90<\mathrm{D}<=120 \\ \text { Yes } & 67 & 11 & 1 & 1 \\ \text { No } & 8 & 3 & 0 & 0 \\ \text { Total } & \mathbf{7 5} & \mathbf{1 4} & \mathbf{1} & \mathbf{1}\end{array}$

Trainings about fish production system and related technologies/information

According to the respondents on the study area, $54 \%$ of them do not get the stated training, while $46 \%$ of them get the training. From the 26 respondents of female headed fishers only nine of them have got the chance to participate on the organized trainings. On the other hand from the 65 respondents of the male headed fishers 33 of them had the access to the organized training. Those who do not get the training was because, no one had given them the access to the training and on the other hand the trainers organize the training when the fishers were busy on their own homework so could not able to participate on the training. Respondents who had access to the training indicated that, the training which has been given to them was easily understandable and practical.

On general according to the result we obtained in the study, trainings and advisory services on fish production and related activities was given to the fishers by woreda experts and development agents. But the fishers do not get information about fishing and related activities from research centers as well as others concerned NGOs. On the other hand there should be a gender analysis prior to giving the training, and this may help us when and where to give the training.

\section{Conclusion and recommendations}

The study was aimed to survey the fisheries' access to information as well as trainings. According to the result obtained, $29 \%$ of the respondents were female headed. And this indicates that women also were one of the actors in the value chain-fish production. And on the other hand the fish producers in the study area had a mean age of 36 years old with 20 years of minimum and 55 years old of the maximum. From this we can depict that most of the fishers are youngsters, so the sector has become the host for youngsters. The result also depicts that $51 \%$ of the respondents had no formal education, while $49 \%$ were above grade one. From the result of the study we can also identified that, $88 \%$ of the respondents had access to fisheries information, from this 23 in head count were female headed fishers and 57 of them were male headed. They got the fisheries information from woreda experts and development agents. The development agents provide the information and advisory service to all this respondents by getting themselves at the fishers' camp. But the majority of the respondents were not getting the training organized by the woreda experts as well as the development agents because, the fishers do not get the chance to the training and also the training was also organized when the fishers were busy with their own job.

The study then recommended that, to have efficient and effective fishing practice the concerned body has to expand the way of transferring technologies to the fishers through electronic media, bulletins and so on. On the other hand the woreda need to arrange trainings according to fishers' preferable schedule.

\section{References}

Abdul Hanan Abdallah1 and Awal Abdul Rahaman 2016. Determinants of Access to Agricultural Extension Services: Evidence from Smallholder Rural Women in Northern Ghana. Asian Journal of Agricultural Extension, Economics \& Sociology 9(3): 1-8, 2016; Article no.AJAEES.23478 ISSN: 2320-7027

Abebe G, and Eshete D, 2012. Fishesof lake Tana: A guide book. Aleme A, and Lemma Z. 2015. Contribution of Livestock Sector in Ethiopian Economy: A Review. International journal of Advances in Life Science 
and Technology V(29).

Agumassie Tesfahun 2018. Review in current problems of Ethiopian fishery: Incase of human and natural associated impacts on water bodies. International Journal of Fisheries and Aquatic Studies 2018; 6(2): 9499.

Amare D, et al 2018. Fishing Condition and Fishers Income: The case of Lake Tana, Ethiopia. International Journal of Aquaculture and Fishery Sciences.

Erkie A. 2017. Water hyacinth (eichhornia crassipses) expansion and the fate of fishers around north eastern part of Lake Tana, Ethiopia. Journal of Business and Management V(01)

Gurmesa Umeta, Felekech Lemecha and Taha Mume 2011. Survey on women access to agricultural extension services at selected districts of Mid Rift Valley of Ethiopia. Journal of Agricultural Extension and Rural Development Vol. 3(3), pp. 51-63

Haruna, M. A., 2Obaroh, I. O.3Yahaya, A. \& 4Muhd. I. U 2015. access of fisheries information to fish farmers in hadejia, north western Nigeria European Journal of Physical and Agricultural Sciences Vol. 3 No. 2, 2015 ISSN 2056-5879

Kaleb Kelemu 2017 Determinants of Farmers Access to Information about Improved Wheat Varieties: Case of farmers in major wheat growing regions of Ethiopia. International Journal of Research in Agricultural Sciences Volume 4, Issue 1, ISSN (Online): 2348 - 3997

Kidanie Misganaw and Addis Getu 2016. Marketing and Livelihood Contribution of Fishermen in Lake Tana, North Western Part of Ethiopia

Mekonnen Sime, FissehaZegeye, BedruBeshir and BezawitYilama 2016 Sources and Access to Agricultural Information of Smallholder Farmers in Central Rift Valley of Ethiopia. A research report108, Ethiopian Institute of Agricultural Research

National Plan Commission (NPC). 2016 GTP II plan of Ethiopia.

Redeat H. 2012. Fishes of Ethiopia: Annotated checklist with pictorial identification guide, first edition.

Selamu Abraham and Lelise Mitiku 2018. Challenges and Socio-Economic Importance of Fish Production in Ethiopia: Review. Journal of Economics and Sustainable Development, Vol.9, No.3, 2018

Veal, A.J. (2005), Business Research Method: A Managerial Approach. Australia: Pearson Education.

Wuletaw M. The link between agricultural production and population dynamics in Ethiopia: a review. Adv Plants Agric Res. 2018; 8(4):348-353. 